\title{
Diel variation in fish assemblages in tidal creeks in southern Brazil
}

\author{
Oliveira-Neto, JF. ${ }^{\mathrm{a} *}$, Spach, HL. ${ }^{\mathrm{a}, \mathrm{b}}$, Schwarz-Junior, . $^{\mathrm{a}, \mathrm{b}}$ and Pichler, HA. ${ }^{\mathrm{a}, \mathrm{b}}$

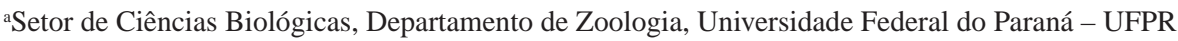 \\ CP 19020, CEP 81531980, Curitiba, PR, Brazil

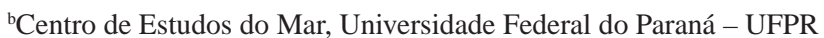 \\ Av. Beira-mar, s/n, Pontal do Sul, CP 50002, CEP 83255-000, Pontal do Paraná, PR, Brazil \\ *e-mail: zechico_77@yahoo.com.br \\ Received February 9, 2006 - Accepted June 16, 2006 - Distributed February 29, 2008
}

(With 2 figures)

\begin{abstract}
Tidal creeks are strongly influenced by tides and are therefore exposed to large differences in salinity and depth daily. Here we compare fish assemblages in tidal creeks between day and night in two tidal creeks in southern Brazil. Monthly day and night, simultaneous collections were carried out in both creeks using fyke nets. Clupeiformes tended to be caught more during the day. Cathorops spixii, Genidens genidens and Rypticus randalli tended to be caught at night. Sciaenidae also tended to be caught more during the night. In general, pelagic species were diurnal, while deep water species were nocturnal. These trends are probably due to a variety of causes, such as phylogeny, predation and net avoidance.
\end{abstract}

Keywords: tidal creeks, fish, diel variation.

\section{Variação diuturna nas assembléias de peixes dos rios de maré do sul do Brasil}

\section{Resumo}

As gamboas são canais com traçado meandrante altamente influenciados pelas marés e sofrem grande variação de salinidade e profundidade em um mesmo dia. O objetivo deste trabalho foi comparar as assembléias de peixes diurna e noturna, e para tanto foram escolhidas duas gamboas no sul do Brasil. Coletas mensais foram feitas simultaneamente na maré vazante da tarde e na maré enchente da noite, com o auxílio de redes fyke. Os clupeiformes exibiram tendência para captura diurna. As espécies: Cathorops spixii, Genidens genidens e Rypticus randalli exibiram forte tendência para captura noturna. A família Sciaenidae também mostrou tendência para captura noturna. De forma geral, espécies pelágicas foram mais capturadas durante o dia, e espécies mais relacionadas ao fundo foram mais capturadas à noite, $\mathrm{e}$ isto se deve à ação conjunta de vários fatores, tais como: padrões filogenéticos, fuga do instrumento de coleta e busca de locais mais protegidos contra predação.

Palavras-chave: gamboas, peixes, variação diuturna.

\section{Introduction}

Fish assemblies are subject to daily variation due to tidal changes and daylight regimes, which are probably most important in shallow waters (Roundtree and Able, 1993). School formation, inactivity, migration, burying and net avoidance are among the main factors that determine which species are caught in nets (Rountree and Able, 1993; In Horn, 1980). For example, schools are generally larger and more common during the day, probably because they offer protection against visually hunting predators. Even nocturnal fish may rest in groups during the day for the same reason. At night, solitary fish or small schools are more common (Helfman, 1993).

Separation of diurnal and nocturnal assemblies is not normally very distinct. Silt and vegetation in the water, or deep waters, permit activity during the day of normally nocturnal fish, while clear nights with moonlight may allow diurnal fish to be active at night (Helfman, 1993; Sogard et al., 1989). Additionally, assemblage structure is interactive: that is, predators and prey can mutually influence the activity of each other (Helfman, 1993). Therefore, collections at the same point at different times of the day (and night) may often show wide differences in the assemblage captured (Gray et al., 1998; Rountree and Able, 1997).

Here we examine the differences in fish assemblages in tidal creeks to better understand the daily light and tide cycles and their influences on fish assemblages.

\section{Methods}

\subsection{Study area}

Pinheiros Bay is in the estuary complex of Paranaguá Bay, in the state of Paraná, in southern Brazil. It is in a region strongly influenced by costal waters, with elevated salinity and $\mathrm{pH}$. Two tidal creeks were chosen for the present study, one in the Ilha das Peças $\left(25^{\circ} 26^{\prime} 252^{\prime \prime} \mathrm{S}\right.$ 
and $48^{\circ} 15^{\prime} 905^{\prime \prime} \mathrm{W}$ ) and the other in the Ilha de Superagüi $\left(25^{\circ} 25^{\prime} 259^{\prime \prime} \mathrm{S}\right.$ and $\left.48^{\circ} 15^{\prime} 115^{\prime \prime} \mathrm{W}\right)$.

\subsection{Sample}

Fyke nets were used to completely close the outlet of both creeks simultaneously. During the afternoon setting tide nets were placed to catch fish as they left the creek. At low tide, fish were removed from the nets and placed in plastic bags on ice. Nets were then reversed to capture the fish entering the creek with the subsequent rising tide. Captures were carried out twice monthly (48 capture periods) for one year from June 2003 to May 2004. Fish were identified by identification keys (Figueiredo and Menezes (1978, 1980, 2000) and Menezes and Figueiredo (1980, 1985)). All fish captured up to 60 individuals chosen randomly from the total were measured (total length, standard length) and weighed. When the number of captured fishes in a given sample exceeded 60, all of the individuals of this species were counted and then weighed together to estimate their total biomass in the respective sample.

\subsection{Analysis}

Species were chosen for analysis as all species of which there was a minimum of 25 captures in four or more months. Species richness (Margalef's index), diversity (Shannon-Wiener), and evenness (Pielou) were calculated for each capture period. Trophic guilds were determined following Chaves and Bouchereau (2004) e Menezes and Figueiredo (1978, 1980, 1985, 2000).

\section{Results}

Diurnal captures included 12,045 individuals and $33.7 \mathrm{~kg}$ biomass (Table 1). The most common species were Anchoa parva (Meek and Hildebrand, 1923), Cetengraulis edentulus (Cuvier, 1829), Harengula clupeola (Cuvier, 1829), Sphoeroides testudineus (Linnaeus, 1758), Atherinella brasiliensis (Quoy and Gaimard, 1825), Oligoplites saliens (Bloch, 1793) and Sphoeroides greeleyi Gilbert, 1900. Both abundance and richness of Engraulidae and Clupeidae were greatest during the day. Six species of carangids were captured, but only $O$. saliens was abundant. Three species of medium-sized sciaenids were caught (Bairdiella ronchus (Cuvier, 1830), Micropogonias furnieri (Desmarest, 1823), Stellifer rastrifer (Jordan, 1889)). Other larger predators were less frequently caught: Centropomus parallelus Poey, 1860 and Strongylura timucu (Walbaum, 1792) were each captured once. Low similarity between daytime captures (37\%) was due to the contribution by $A$. parva $(33 \%)$ and S. testudineus (37\%), both of whose occurrences were quite variable during the year (Table 2).

Nocturnal captures $(n=1,710)$, with fewer individuals, tended towards larger individuals or species as their contribution to the total biomass was $57 \%$ (44.4 kg). $S$. testudineus, B. ronchus, Rypticus randalli Courtenay, 1967, Genidens genidens (Cuvier, 1829), Cathorops spixii (Agassiz, 1929) and S. greeleyi were dominant species. Cynocion sp. Gill, 1861, M. furnieri and S. rastrifer (all belonging to the family Sciaenidae) comprised over $13 \%$ of the total number of captures due to the large number of juveniles. Tetraodontiformes dominated in number of individuals and biomass. Clupeiformes included uncommon species, such as Chirocentrodon bleekerianus (Poey, 1867), Pellona harroweri (Fowler, 1917), and larger and rare specimens of $H$. clupeola (17 cm total length) and Anchoa lyolepis (Evermann and Marsh, 1900) (10 cm). Similarity among nocturnal captures was high (Table 2), mostly caused by constancy frequencies in captures of tetraodontids and Bairdiella ronchus.

Filter-feeders and pelagic species (engraulids and clupeids) were most common in captures during the day (Figure 1). The vast majority (>96\%) of A. parva, A. tricolor and $C$. edentulus were captured during the day. Carangids were captured during the day as well as Oligoplites saurus (Bloch and Schneider, 1801), Caranx lattus Agassiz, 1831, Caranx hippos (Linnaeus, 1766) and Selene vomer (Linnaeus, 1758). Besides O. saliens, only Chloroscombrus chrysurus (Linnaeus, 1766) appeared in night captures. On the other hand, Rypticus randalli, Cathorops spixii, 2 pristegasterids and 3 sciaenids were only captured at night (Table 1). A larger number of B. ronchus, G. genidens and S. testudineus were captured at night (Figure 2).

\section{Discussion}

Tidal creek assemblages change from day to night (Lin and Shao, 1999) and so differ from other environments, such as beaches (Ross et al., 1987; Lin and Shao, 1999; Pessanha et al., 2003), where variation may be subtler. In general, daytime samples, which included engraulids, clupeids, atherinids and tetraodontids, were similar to net samples in tidal flats during the day (Pichler, 2005). On the other hand, there was a similarity in species composition between nocturnal samples and diurnal samples of bottom waters, including several ariids and sciaenids (Schwarz Junior, 2005).

The capture pattern of several families in the present study was consistent with that observed in other studies. Pellona harroweri tends to be captured at night (Lopes, 1993; Oliveira Neto et al., 2004, Barreiro et al., 2004). C. bleekerianus and P. harroweri were also commonly captured in bottom waters during the day (Schwarz Jr., 2005) but not in tidal creeks. Mugilids tend to be nocturnal, especially Mugil curema Valenciennes, 1836, in tidal flats (Oliveira et al, 2004), and estuarine beaches (Pessanha and Araújo, 2003). However, this schooling species (Menezes, 1980) showed no evident diel patterns in other studies (Sogard et al., 1989), which may be due to sampling problems associated with schooling. Carangids are usually occasionally and diurnally captured (Rooker and Dennis, 1991; Pessanha and Araújo, 2003). Sciaenids were much more frequent in nocturnal samples as found in Canto Grande in the state of Santa Catarina (Barreiros et al., 2004), and in tidal flats in Paranaguá Bay (Oliveira Neto et al., 2004). Two common ariids in Paranaguá Bay are nocturnal in shallow waters (Oliveira Neto et al., 2004), 
Table 1. Number of captures and biomass at each capture interval of the species captured in the tidal creeks of Pinheiros Bay, Paraná.

\begin{tabular}{|c|c|c|c|c|c|c|}
\hline \multirow[t]{2}{*}{ Family/ Species } & \multicolumn{3}{|c|}{ Number of captures } & \multicolumn{3}{|c|}{ Biomass (g) } \\
\hline & Day & Night & Total & Day & Night & Total \\
\hline \multicolumn{7}{|l|}{ ENGRAULIDAE } \\
\hline Anchoa lyolepis & 8 & 1 & 9 & 5.6 & 5.6 & 11 \\
\hline Anchoa parva & 9365 & 394 & 9759 & 8520 & 545 & 9065 \\
\hline Anchoa tricolor (Agassiz, 1829) & 52 & 2 & 54 & 38 & 1 & 39 \\
\hline Anchoa sp. & 1 & - & 1 & $>1$ & - & \\
\hline Cetengraulis edentulus & 1222 & 27 & 1249 & 2774 & 75 & 2849 \\
\hline Lycengraulis grossidens (Agassiz, 1829) & 16 & 6 & 22 & 488 & 143 & 631 \\
\hline \multicolumn{7}{|l|}{ CLUPEIDAE } \\
\hline Sardinella brasiliensis Steidachner, 1859 & 15 & - & 15 & 16 & - & 16 \\
\hline Opisthonema oglinum (Lesueur, 1817) & 24 & - & 24 & 22 & - & 22 \\
\hline Harengula clupeola & 624 & 11 & 635 & 1704 & 73 & 1777 \\
\hline \multicolumn{7}{|l|}{ PRISTIGASTERIDAE } \\
\hline Chirocentrodon bleekerianus & - & 3 & 3 & - & 1.6 & 2 \\
\hline Pellona harroweri & - & 2 & 2 & - & 9 & 9 \\
\hline \multicolumn{7}{|l|}{ ARIIDAE } \\
\hline Cathorops spixii & - & 50 & 50 & - & 2053 & 2053 \\
\hline Genidens genidens & 2 & 35 & 37 & 122 & 2344 & 2466 \\
\hline \multicolumn{7}{|l|}{ MUGILIDAE } \\
\hline Mugil curema & - & 5 & 5 & - & 773 & 773 \\
\hline Mugil gaimardianus Desmarest, 1831 & 1 & 1 & 2 & 79 & 101 & 180 \\
\hline Mugil sp. & 4 & 1 & 5 & 1.00 & 0.07 & 1 \\
\hline \multicolumn{7}{|l|}{ ATHERINOPSIDAE } \\
\hline Atherinella brasiliensis & 130 & 10 & 140 & 2015 & 109 & 2124 \\
\hline \multicolumn{7}{|l|}{ BELONIDAE } \\
\hline Strongylura marina (Walbaum, 1792) & - & 1 & 1 & - & 51 & 51 \\
\hline Strongylura timucu & 1 & 0 & 1 & 28 & - & 28 \\
\hline \multicolumn{7}{|l|}{ HEMIRHAMPHIDAE } \\
\hline Hyporhamphus unifaciatus & 5 & 7 & 12 & 66 & 67 & 133 \\
\hline Hemirhamphus brasiliensis & - & 3 & 3 & - & 29 & 29 \\
\hline \multicolumn{7}{|l|}{ TRIGLIDAE } \\
\hline Prionotus sp. & - & 1 & 1 & - & 0.19 & 0 \\
\hline \multicolumn{7}{|l|}{ CENTROPOMIDAE } \\
\hline Centropomus parallelus & 1 & 3 & 4 & 21 & 351 & 372 \\
\hline Centropomus sp. & 2 & 10 & 12 & 1.5 & 5.1 & 7 \\
\hline \multicolumn{7}{|l|}{ CARANGIDAE } \\
\hline Caranx hippos & 1 & - & 1 & 34 & 0 & 34 \\
\hline Caranx latus & 1 & - & 1 & 3 & - & 3 \\
\hline Chloroscombrus chrysurus & 1 & 1 & 2 & 1 & 0.81 & 2 \\
\hline Oligoplites sauros & 3 & - & 3 & 5 & - & 5 \\
\hline Oligoplites saliens & 152 & 2 & 154 & 2924 & 44 & 2968 \\
\hline Selene vomer & 2 & - & 2 & 73 & - & 73 \\
\hline \multicolumn{7}{|l|}{ GERREIDAE } \\
\hline Eugerres brasilianus (Cuvier, 1830) & - & 1 & 1 & - & 230 & 230 \\
\hline Diapterus rhombeus & 4 & 10 & 14 & 99 & 340 & 439 \\
\hline Eucinostomus argenteus & 19 & 2 & 21 & 389 & 0.76 & 390 \\
\hline Eucinostomus gula (Quoy and Gaimard, 1824) & 1 & - & 1 & 23 & - & 23 \\
\hline Eucinostomus melano & 1 & - & 1 & 22 & - & 22 \\
\hline \multicolumn{7}{|l|}{ HAEMULIDAE } \\
\hline Anisotremus surinamensis & - & 1 & 1 & - & 1 & 1 \\
\hline
\end{tabular}


Table 1. Continued...

\begin{tabular}{|c|c|c|c|c|c|c|}
\hline \multirow[t]{2}{*}{ Family/Species } & \multicolumn{3}{|c|}{ Number of captures } & \multicolumn{3}{|c|}{ Biomass (g) } \\
\hline & Day & Night & Total & Day & Night & Total \\
\hline \multicolumn{7}{|l|}{ SCIAENIDAE } \\
\hline Bairdiella ronchus & 25 & 187 & 212 & 605 & 10002 & 10607 \\
\hline Micropogonias furnieri & 4 & 52 & 56 & 148 & 582 & 730 \\
\hline Stellifer rastrifer & 1 & 137 & 138 & 19 & 107 & 126 \\
\hline Isopisthus parvipinnis (Cuvier, 1830) & - & 6 & 6 & - & 187 & 187 \\
\hline Cynocion acoupa (Lacepède, 1801) & - & 1 & 1 & - & 57 & 57 \\
\hline Cynocion sp. & - & 45 & 45 & - & 34 & 34 \\
\hline \multicolumn{7}{|l|}{ SERRANIDAE } \\
\hline Rypticus randalli & - & 48 & 48 & - & 835 & 835 \\
\hline \multicolumn{7}{|l|}{ GOBIIDAE } \\
\hline Ctenogobius shufeldti & - & 2 & 2 & - & 1 & 1 \\
\hline \multicolumn{7}{|l|}{ BATRACHOIDIDAE } \\
\hline Porichthys porosissimus (Cuvier, 1829) & - & 1 & 1 & - & 0.8 & 1 \\
\hline \multicolumn{7}{|l|}{ EPHIPPIDAE } \\
\hline Chaetodipterus faber (Broussonet, 1782) & - & 1 & 1 & - & 117 & 117 \\
\hline \multicolumn{7}{|l|}{ OPHICTHIDAE } \\
\hline Ophichthus gomesii (Castelnau, 1855) & - & 1 & 1 & - & 24 & 24 \\
\hline \multicolumn{7}{|l|}{ ACHIRIDAE } \\
\hline Achirus lineatus & - & 1 & 1 & - & 1.2 & 1 \\
\hline \multicolumn{7}{|l|}{ PARALICHTHYIDAE } \\
\hline $\begin{array}{l}\text { Citharichthys arenaceus Evermann and } \\
\text { Marsh, } 1900\end{array}$ & 4 & 4 & 8 & 79 & 31 & 110 \\
\hline Citharichthys spilopterus Günther, 1862 & 4 & - & 4 & 161 & - & 161 \\
\hline Citharichthys sp. & 2 & 1 & 3 & 0.29 & 0.07 & 0 \\
\hline \multicolumn{7}{|l|}{ SYNOGLOSSIDAE } \\
\hline $\begin{array}{l}\text { Symphurus tesselatus (Quoy and } \\
\text { Gaimard, 1824) }\end{array}$ & - & 1 & 1 & - & 20 & 20 \\
\hline \multicolumn{7}{|l|}{ DIODONTIDAE } \\
\hline Chilomycterus spinosus (Linnaeus, 1758) & 6 & 11 & 17 & 4 & 11 & 15 \\
\hline \multicolumn{7}{|l|}{ TETRAODONTIDAE } \\
\hline Sphoeroides testudineus & 268 & 554 & 822 & 11995 & 24291 & 36286 \\
\hline Sphoeroides greeleyi & 73 & 67 & 140 & 1249 & 825 & 2074 \\
\hline Total & 12045 & 1710 & 13755 & 33729 & 44474 & 78202 \\
\hline
\end{tabular}

Table 2. Similarity analysis (SIMPER) of the percentage of the samples from Low-tide/Daytime (D) and High-tide/Nighttime (N) of the dominant species of this study in Pinheiros Bay, Paraná.

\begin{tabular}{|c|c|c|c|}
\hline \multirow[t]{2}{*}{ Species } & \multicolumn{2}{|c|}{ Similarity } & \multirow{2}{*}{$\begin{array}{c}\text { Dissimilarity } \\
\mathrm{D} \times \mathrm{N}(66 \%)\end{array}$} \\
\hline & D $(37 \%)$ & $\mathbf{N}(50 \%)$ & \\
\hline Sphoeroides testudineus & 37 & 42 & 15 \\
\hline Anchoa parva & 33 & 8 & 17 \\
\hline Sphoeroides greeleyi & 14 & 11 & 8 \\
\hline Harengula clupeola & 5.5 & $* * *$ & 7 \\
\hline Atherinella brasiliensis & 4.5 & $* * *$ & 6 \\
\hline Genidens genidens & $* * *$ & 7 & 7 \\
\hline Rypticus randalli & $* * *$ & 5 & 5.5 \\
\hline Bairdiella ronchus & $* * *$ & 19 & 13 \\
\hline Anchoa tricolor & $* * *$ & $* * *$ & 5 \\
\hline Cetengraulis edentulus & $* * *$ & $* * *$ & 4 \\
\hline
\end{tabular}



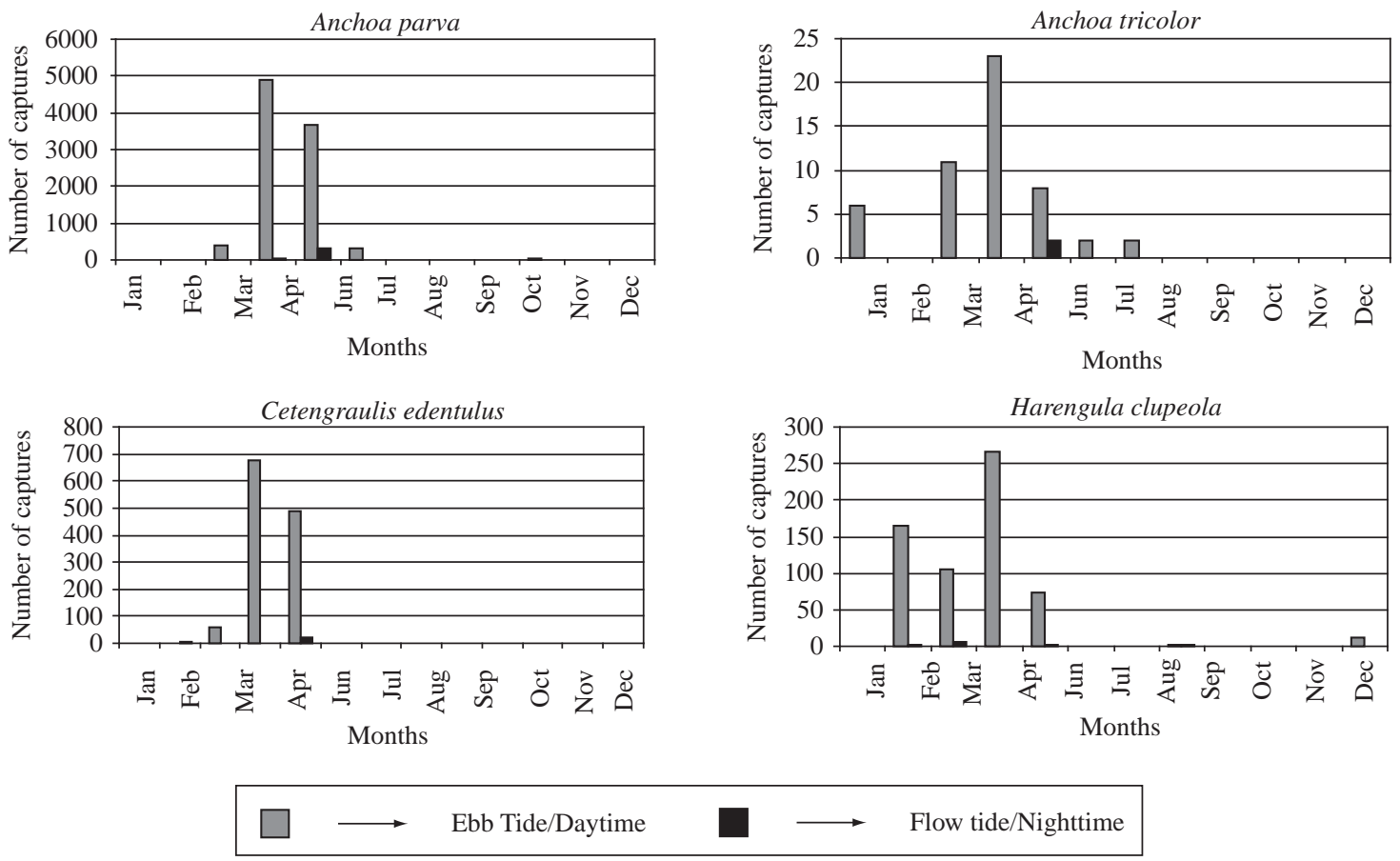

Figure 1. Daily and monthly variation in capture abundance of four species of Clupeiformes that were dominant in the tidal creeks of Pinheiros Bay, Paraná. da Baía dos Pinheiros, Paraná, showing the superior number of day captures of this group.
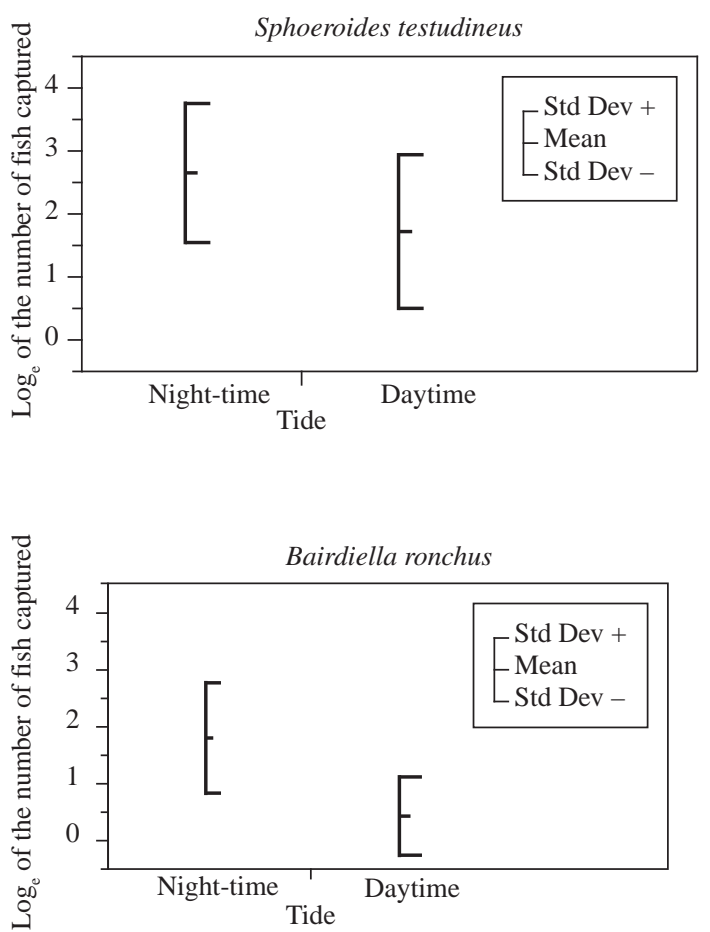

Figure 2. Capture abundance of two dominant species at night-time and daytime tides, in Pinheiros Bay, Paraná, showing the superior number of night captures although by day may be caught in large numbers in deeper waters (Schwarz Jr., 2005). Ariids were uncommon in tidal flats of Pinheiros Bay (Pichler, 2005), which also suggests that they are rare by day in shallow waters.

Samples were strongly influenced by the presence of fish schools. Given that schools tend to occur during the daytime (Helfman, 1993), the clustered distribution of specimens of schooling fish in that period can decrease their probability of being captured in any given sample. On the other hand, when a sample does include schooling fish species, their abundance in that sample can be high. This phenomenon might explain the occurrence pattern of O. saliens and Eucinostomus argenteus Baird; Girard, 1855 , which was characterized by a relatively long absence from samples that were punctuated by the sudden appearance of a school. However, there were instances when schools were frequent during several consecutive months, such as in the case of the clupeiforms A. parva, $C$. edentulus and $H$. clupeola. Those species were very common, forming very large schools during the day, whereas during the night they were rare. A similar behavior was observed in Anchoa michilli (Valenciennes, 1848), which formed schools in tidal creeks during the day as a form of protection, and searched other environments at night during foraging (Reis and Dean, 1981). Following the nocturnal dispersal of these clupeiform fishes, the number of individuals within the tidal creeks decreases. This might cause an increase in their abundance in other areas, as has been recorded in other places, 
such as beaches (Pessanha and Araújo, 2003; Pessanha et al., 2003).

However, the most common pattern was an increase in the abundance of the species in nocturnal samples. This increase was probably due to the movement of individuals from other regions into the tidal creeks. This could explain why nocturnal samples had higher species richness (Nash, 1986). Most of the species that were found only during the day or the night were rare, except for $C$. spixii and $R$. randalli. In the case of sciaenids and ariids, the fish remain inactive and/or grouped during the day outside the tidal channels, probably in deeper areas. During the night, sciaenids and ariids reach the tidal creeks due to the increase in their occupation area. This pattern might also include other demersal species, a pattern that would explain why diurnal samples in tidal creeks became similar to nocturnal demersal samples. Therefore, the phenomenon of grouping schooling and dispersal affects very distinct families in a very similar fashion. The differences pertain to the preferred grouping sites during the day (e.g. tidal creeks, deeper waters) and the potential sites for dispersal or dislocation during the night (beaches, shallow waters). Phylogenetic constraints might represent an important factor underlying the patterns observed in the present study. For instance, species that occupy demersal environments are adapted to low light conditions, a factor that might explain why their occurrence in shallow environments usually occurs at night. The differences between diurnal and nocturnal samples might also result from the higher visibility of the net during the day, a factor that could reduce its efficiency (Nash, 1986; Horn, 1980). Likewise, very translucent waters would decrease the efficiency of the capture nets because of their visibility to the fish (Hoese, 1973). Even though these hypotheses are plausible, their impact should not be overestimated. In a study conducted in the Lagoa dos Patos, a slightly higher number of individuals was collected during the day (Pereira, 1994). In addition, capture rates were even higher in conditions of high water transparency. The collected biomass was also higher during the day in another study in the region of the Baía de Paranaguá (Godefroid et al., 1998). Also, Horn (1980) and Lin et al. (1999) found negligible differences in the biomass of dominant species between diurnal and nocturnal samples, a result that is also inconsistent with the hypotheses presented above. In the case of a few demersal species, such as $S$. greeleyi and E. argenteus, diurnal samples were similar or larger than nocturnal samples. In conclusion, there are several lines of evidence indicating that the results shown by our samples are not artifactual, particularly when the differences between diurnal and nocturnal samples are as high as the ones observed for ariids and sciaenids.

\section{Conclusions}

Most of the pelagic species (families Clupeidae, Engraulidae, Carangidae) were most commonly collected during the day, regardless of where they reside in the trophic web, whereas most of the demersal species tend towards nocturnality (families Tetraodontidae, Sciaenidae, Ariidae). The principal factor that determines the daily cycle of many species appears to be schooling and migratory behaviors.

\section{References}

BARREIROS PJ., FIGNA, V. and HOSTIN-SILVA, M., SANTOS, RS. 2004. Diel Seasonlity of a Shallow-Water Fish Assemblage in a Sandy Beach at Canto Grande, Santa Catarina, Brazil. Journal of Coastal Research, special issue, no. 42.

CHAVES, P. and BOUCHEREAU, JL., 2004. Trophic organization and functioning of fish populations in the Bay of Guaratuba, Brazil, on the basis of a trophic contribution factor. Acta Adriat., vol. 45, no. 1, p. 83-94.

ESPER, MLP., 1982. Reprodução e crescimento de Anchoa januaria (Steindachner, 1879) na região de Ponta da Cruz (Baía de Paranaguá), Paraná, Brasil. Dusenia, Curitiba, vol. 13, no. 1, p. $15-35$.

GODEFROID, RS., HOFSTAETTER, M. and SPACH, HL, 1998. Moon, tidal and diel influences on catch composition of fishes in the surf zone of the beach at Pontal do Sul, Paraná. Revista Brasileira de Zoologia, vol. 15, no. 3, p. 697-701.

GRAY, CA., CHICK, RC. and McELLIGOTT, DJ., 1998. Diel chenges in assemblages of fishes associated with shallow seagrass and bare sand. Estuarine, Costal and Shelf Science, vol. 46, p. 849-859.

HELFMAN, GS., 1993. Fish behaviour by day, night and twilight. In Pitcher Behaviour of teleost fishes. Chapter fourteen. $2^{a}$ edn Edited by TONY J. PITCHER, Editor PITCHER, TJ. p. 479-512. Londres.

HOESE, HD., 1973. A trawl study of nearshore fishes and invertebrates of the georgia coast. Contributions in Marine Science, vol. 17, p. 63-98.

HORN, MH., 1980. Diel and seasonal variation en abundance and diversity of shallow-water fish populations in Morro Bay, California. Fishery Bulletin. vol. 78, no. 3, p. 759-769.

LIN, HJ. and SHAO, KT., 1999. Seasonal and diel changes in a subtropical mangrove fish assemblage. Bulletin of Marine Science, vol. 65, p. 775-794.

FIGUEIREDO, JL. and MENEZES, NA., 1978. Manual de peixes marinhos do Brasil. II. Teleostei (1). Museu de Zoologia. Universidade de São Paulo. 110 p.

-,1980. Manual de peixes marinhos do Brasil. IV. Teleostei (3). Museu de Zoologia. Universidade de São Paulo. 96 p.

-, 2000. Manual de peixes marinhos do Brasil. VI. Teleostei (5). Museu de Zoologia. Universidade de São Paulo. 116 p.

LOPES, RG., RODRIGUES, ES., PUZZI, A., PITA, JB., COELHO, JAP. and FREITAS, ML., 1993. Levantamento ictiofaunístico em um ponto fixo de Santos, estado de São Paulo, Brasil. Boletim do Instituto de Pesca, vol. 20, p. 7-20.

MENEZES, NA. and FIGUEIREDO, JL., 1980. Manual de peixes marinhos do Brasil. III. Teleostei (2). Museu de Zoologia. Universidade de São Paulo. 89 p.

-, 1985. Manual de peixes marinhos do Brasil. V. Teleostei (4). Museu de Zoologia. Universidade de São Paulo. 105 p. 
NASH, RDM., SANTOS, RS. and HAWKINS, SJ., 1994. Diel fluctuations of sandy beach fish assemblage at Porto Pim, Faial Island, Azores. Arquipélago. Life and Marine Sciences, vol. $12 \mathrm{a}$, p. $75-86$.

NASH, RDM., 1986. Diel fluctuations of shallow water fish community in the Inner Oslofjord, Norway. Marine Ecology, vol. 7, no. 3, p. 219-232.

OLIVEIRA NETO, JF., GODEFROID RS., QUEIROZ, GMLN. and SCHWARZ JUNIOR, R., 2004. Variação diuturna na captura de peixes em uma prlanície de maré da baía de Paranaguá, PR. Acta Biológica Leopoldensia, vol. 26, no. 1, p. 125-138.

PEREIRA, LE., 1994. Variação diurna e sazonal dos peixes demersais na Barra do Estuário da Lagoa dos Patos, RS. Atlântica, Rio Grande, p. 5-21.

PESSANHA, ALM. and ARAÚJO, FG., 2003. Spatial, temporal and diel variations of fish assemblages at two sandy beaches in the Sepetiba Bay, Rio de Janeiro, Brazil Estuarine, Coastal and Shelf Science, vol. 57, p. 817-828.

PESSANHA, ALM., ARAÚJO, FG., AZEVEDO, MCC. and GOMES, ID., 2003. Diel and seasonal changes in the distribution of fish on a southeast Brazil sandy beach. Marine Biology, vol. 143, no. 6, p. 1047-1055.

PICHLER, HA., 2005. A ictiofauna em planícies de maré da Baía dos Pinheiros, Paraná. Curitiba, (Dissertação - Mestre em Zoologia) - Setor de Ciências Biológicas, Universidade Federal do Paraná.
REIS, RR. and DEAN, JM., 1981. Temporal variation in the utilization of an intertidal creek by the Bay Anchovy (Anchoa mitchilli). Estuaries, vol. 4, no. 1, p. 16-23.

ROOKER, JR. and DENNIS, GD., 1991. Diel, lunar and seasonal changes in a mangrove fish assemblage off southern Puerto Rico. Bulletin of Marine Science, vol. 49, p. 684-698.

ROUNTREE, RA. and ABLE, KW., 1993. Diel variation in decapoda crustacean and fish assemblages in New Jersey polyhaline marsh creeks. Estuarine, Coastal And Shelf Science, vol. 37 , no. 181-201.

ROUNTREE, RA. and ABLE, KW., 1997. Nocturnal fish use of New Jersey marsh creek and adjacent bay shoal habitats. Estuarine, Coastal And Shelf Science, vol. 44, no. 6, p. 703-711.

ROSS, ST., MCMICHAEL JR, RH.and RUPLE, DL., 1987. Seasonal and diel variation en the standing crop of fishes and macroinvertebrates from a gulf of Mexico surf zone. Estuarine, Coastal and Shelf Science, vol. 25, no. 4, p. 391-412.

SCHWARZ JR., R., 2005. A ictiofauna demersal da Baía dos Pinheiros, Paraná. Curitiba, p. 71. (Dissertação - Mestre em Zoologia) - Setor de Ciências Biológicas, Universidade Federal do Paraná.

SOGARD, SM., POWELL, GVM. and HOLMQUIST, JG., 1989. Utilization by fishes of shallow, seagrass-covered banks in Florida Bay: 2. Diel and tidal patterns. Environmental Biology of Fishes, vol. 24, no. 2, p. 81-92. 
